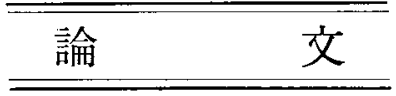

日本金属学会說 第 45 巻 第 5 年(1981) 449 456

\title{
两鉛の変形双晶の形成に伴う $\mathrm{AE}$
}

\begin{abstract}
栗林一彦*岸輝 雄* 堀内 良*
J. Japan Inst. Metals, Vol.45, No.5(1981).pp.449 456

Kinematical Study of Deformation Twinning in Zinc by means of Acoustic Emission

Kazuhiko Kuribayashi*, Teruo Kishi* and Ryo Horiuchi*

The effect of deformation twinning on $\mathrm{AE}$ in zinc single and polycrystals was evaluated quantitatively. AE observed at the stage II deformation of zinc single crystal consists of a mixture between continuous type emission and burst type emission. The former corresponds to the basal slip, and the latter to the deformation twinning. The fraction of deformation twinning to the total amount of the plastic deformation was estimated to be 0.3 on the basis of the analysis of the distribution of $\mathrm{AE}$ amplitudes. The $\mathrm{AE}$ behavior during the tensile test of zinc polycrystals could be well explained by the kinetics with respect to the multiplication and the annihilation of dislocations. Particulary the strain rate dependence of $\mathrm{AE}$ activity in zinc polycrystal could be well explained by the present kinematical analysis.
\end{abstract}

(Received July 17, 1980)

\section{I. 舶言}

Acoustic Emission (AE) とは,種々の固体材料が変形， あるいは破壊する時に，外力の行なった仕事の一部が音波 となって放出される過程のことであり，材料の変形，ある いは破壊の機構と密接に結びついているものと期待され $ろ^{(1)}$.

Kaiser 効果 (2) として知られているAE の不可逆性の研 究以後, $\mathrm{AE}$ と変形の不均一性との相関 ${ }^{(3)}$ は Fisher と Lally ${ }^{(4)}$ によって実験的に証朋され，Gillis と Hamstad ${ }^{(5)}$ によって定式化された，その後，これらの考光方は， Lüders 変形 ${ }^{(6)}$, serration ${ }^{(7)}$ 等の不均一変形,さらには転 位の unlocking ${ }^{(8)(9)}$, Neumann バースト ${ }^{(10)}$ 亿対して適用 されてきている。一方,理論的には Stephens とPollock ${ }^{(11)}$ や Malen と Bolin ${ }^{(12)}$ 化よって局所的な塑性ひずみと応力 波との関係が研究されて打り，AEの大きさ支配するも のとしては, 変形量と変形域の大きさ，おょび变形に伴 応力の降下に要する時間 $(\Delta t)$ の大小が重要であることが示 されている.最近では，变形の時問変化を含む取扱いによ り，筆者ら ${ }^{(13)}$ Kっって転位モデルを導入した動的な $\mathrm{AE}$ 発生モデルる提案されている。これらのモデルより，材料 内の局所的な変位速度, あるいは変位加速度は，AE の強 度を直接的に支配していることが理解される。したがっ て, 通常の $f c c$ 純金属中の転位の移動速度 ${ }^{(14)}$ に比して,

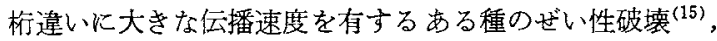
マルテンサイト変態(16)あるいは変形双晶の形成，伀播 ${ }^{(17) ，}$ は，大きな $\mathrm{AE}$ の原因となることが容易に理解される。特 に，变形双晶の形成，伀播はするどい AEインパルスを生 $\mathfrak{l}^{(18)}$ ，転位の運動とともに金属の变形の機構を考古る際 の重要な要素となっている。しかしながら， AE に対する 変形双昆の寄与を，単独に抽出して，定量的に評唏した例 は，ほとんど報告されていないのが現状である。本研究で は, 以上の点を考虑して，特记 $\mathrm{AE}$ 比対する変形双晶の効 果と，転位の運動によるすべりの効果を分離して評価する 手法を考察し，結晶粒度や，ひずみ速度の変形双晶の形成 に执よ汸す影響をしらべることを主な目的としている。

\section{iII. 実 験 方 法}

用いた試験片は，平行部が $4 \times 4 \times 30 \mathrm{~mm}^{3}$ の角柱状の Zn 単結晶，多結晶であり，素材は，いずれも $99.99 \%$ 以 上の純度を有する電解再鉛から溶解，压延を経て作製され た、単結晶は，高純度のアルミナ粉末を固めたい和ゆるソ フトモールドを用いることにより，引き上げ速度が 40 $\mathrm{mm} / \mathrm{h}$ のBridgman 法によって作製された。

$\mathrm{AE}$ の測定に用いられたエレクトロニクスのブロックダ イヤグラムはFig.1に示されている。用いられた AE 変 換子は PZT $\left(\mathrm{PbZrO}_{3} \cdot \mathrm{PbTiO}_{3}\right)$ の厈電素子から構成されて 㧍り，感度は “HANSFACS” 方式 ${ }^{(19)}$ とよる絶対感度較正

* 東京大学宇宙航空研究所(Institute of Space and Aeronautical Science, The University of Tokyo, Tokyo) 


\section{Strain Amp.}

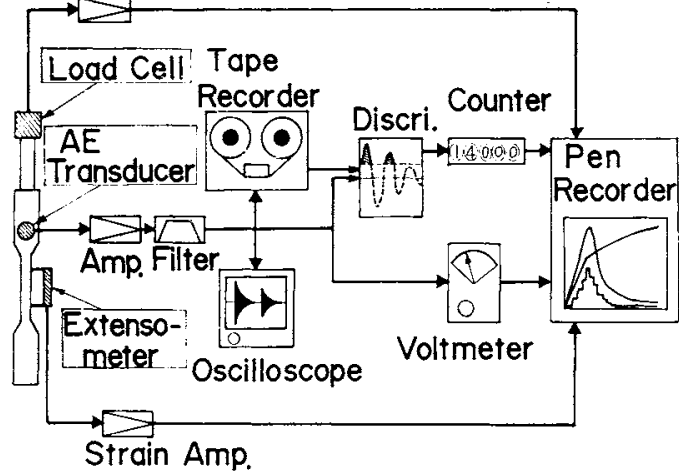

Fig.1 Block diagram of the electronic set-up.

法によって測定されて拉り，共振の中心周波数が $140 \mathrm{kHz}$ 付近になるように設計されている。AE 信号は，線型堌幅 器により 50〜70 dB 增幅された後に，比較的低周波の機械 的雑音を除去する目的で $20 \mathrm{kHz} \sim 200 \mathrm{kHz}$ の通過帯域を 有するバンドパスフィルタによってろ波されている，AE 信号快，その後，実效值電圧 $\left(A E_{m}\right)$ ，あるいはリングダウ ン計数として処理され，それらの出力は，負荷荷重ととも に試験片の伸びに対してX- $\mathrm{Y}_{1}, \mathrm{Y}_{2}, \mathrm{Y}_{3}$ レコーダによって 記録されている。エレクトロニクスシスデム全体としての 熱雑音 $\left(A E_{n}\right)$ は, 増幅器への入力信号に換算して $5.5 \mu \mathrm{V}$ 程度に検出されるので，実効値電圧としての $\mathrm{AE}$ 信号 $\left(A E_{r m s}\right)$ は

$$
A E_{r m s}=\left\{\left(A E_{m}\right)^{2}-\left(A E_{n}\right)^{2}\right\}^{1 / 2}
$$

として求められている，AEのリングダウン計数の積分モ ード振幅分布は，データレコーダに収録された $\mathrm{AE}$ 信号を 繰り返して再生することにより PHA (波高弁别器)より求 められている。

\section{III。実 験 結 果}

\section{Zn 単結晶の変形に伴う $\mathrm{AE}$ とその振幅分布}

$h c p$ 構造を有する $\mathrm{Zn}$ と Cd の単結晶，多結晶において は活動しうるすべり系は，通常は (0001)-[112̄1] の底面す ベりのみであり，柱面すべり等の高次のすべり采は，高温 等の特殊な条件下以外は，一般には活動しないことが知ら れている(20). 変形双晶は, 底面すべりが容易に活動するよ うな結晶方位で，基本的には形成されず，变形双晶の形 成の確率の高い方位では，底面すべりが容易に活動するた めの補助的な作用をすると考光ることにより理解される。

Fig.2 は変形双晶の形成の確率の高い結晶方位を有する $\mathrm{Zn}$ 単結晶の応力・ひずみ曲線と，同時に測定された $\mathrm{AE}$ 実效值電圧の発生パターンを示したるのである。このよう な結晶方位に打いては， $f c c$ 金属単結晶の変形に打いて知 られている変形の旮れでれの stage は明膫ではないが, 現 象論的儿は約 $4 \%$ 塑性ひず文での比較的加工硬化の小さ な領域が stage I, それ以後の, 変形双晶の形成汇対灾し
て応力・ひずみ曲線上に鋸齿状の段差が生じている領域が stage II と分類される。 $\mathrm{AE}$ 実効值電圧の発生パターンむ 变形の各 stage と対応して拈り, stage Iでは比較的变化 がすくなく， stage IIでは变形双晶の形成に伴うするぞ いインバルス状の $\mathrm{AE}$ が観察されている。一方，Fig.2に 示された結晶方位に比して，相刘的に，变形双晶の形成の 確率の低い結晶方位を有する $\mathrm{Zn}$ 単結晶に执いては， Fig.3 に示されているように，加工硬化は小さく， $\mathrm{AE}$ 実

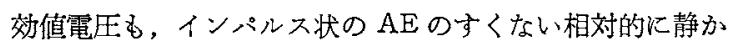
なパターンを示している，Fig.2 に示された $\mathrm{AE}$ のリング ダウン計数の積分モードの振幅分布は Fig.4 亿示されて 招り, stage I と stage II で灶大きく異った分布形態を 示している.

振幅值 $V_{t}$ を有する $\mathrm{AE}$ のリングダウン計数の積分モ一 ド振幅分布 $I\left(V_{t}\right)$ は， $\mathrm{AE}$ 変換子の共振周波数を $k_{0}$ とする と

$$
I\left(V_{t}\right)=k_{0} \exp \left(-a V_{t}^{m}\right)
$$

と表わさ礼る。ただし，aは実效值電圧に传存した俰数で ある， $m=2$ (ガウス分布) は連続型 AE 注対応し， $m=1 / 2$ は突発型 $\mathrm{AE}$ に対応する(21).

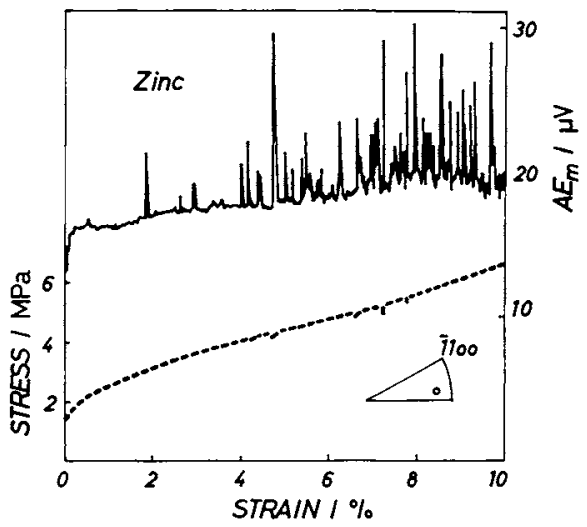

Fig.2 $\mathrm{AE}$ behavior and the related stress-strain curve in zinc single crystal which has a favorable orientation for deformation twinning.

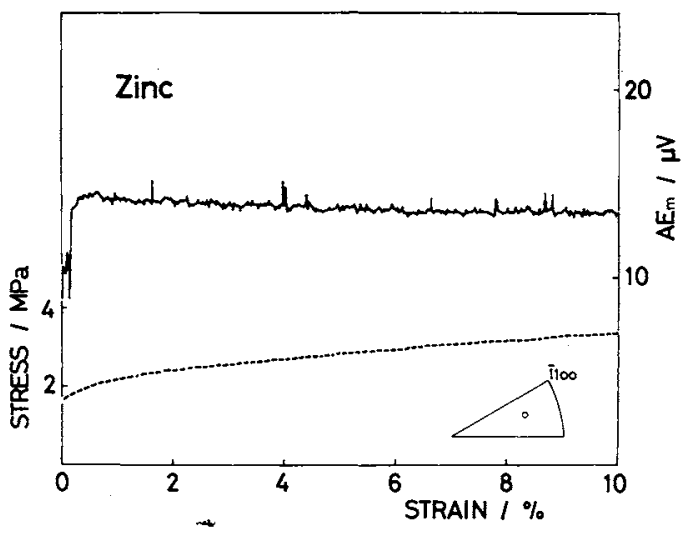

Fig.3 AE behavior and the related stress-strain curve in zinc single crystal which has an unfavorable orientation for deformation twinning. 


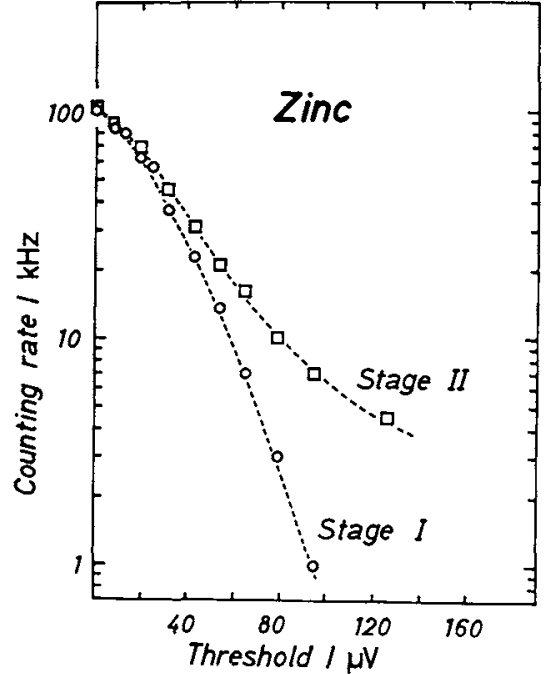

Fig.4 Distribution of AE amplitudes in the plastic deformation of zinc single crystal.

$\mathrm{Zn}$ 単結晶の stage I の AEのリングダウン計数の積分モ ード振幅分布は, Fig.5に示されているように $m=2$ の成 分で表わされ，stage IIK秃いては，Fig.6に示されて いるよらに $m=1 / 2$ の成分と $m=2$ の成分の和で表わされ る。このことは, stage Iでは, $\mathrm{AE}$ は底面上の転位の比 較的均一なすべり運動による連続型成分であり， stage II では，AEは上述のすべりとよる遭続型成分と，不均一な変 形双晶の形成に伴ら突登型成分との共存した状態で規定さ れると考光られる。実際，グラウン管上で AE の波形を観 察すると，Fig.7に示されているように， stage Iでは連 続型 $\mathrm{AE}$ であり, stage II では連続型 $\mathrm{AE}$ と突発型 $\mathrm{AE}$ の搌合状態であることが理解される。

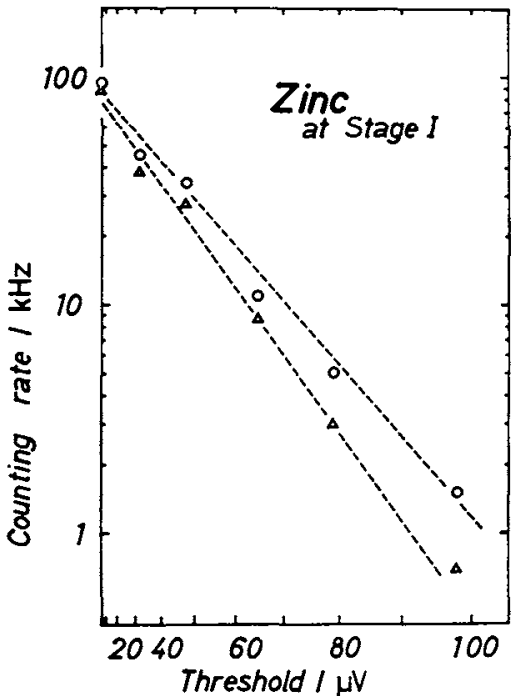

Fig.5 Distribution of $\mathrm{AE}$ amplitudes in the stage I deformation of zinc single crystal. The abscissa indicates the square of the threshold $(m=2)$.

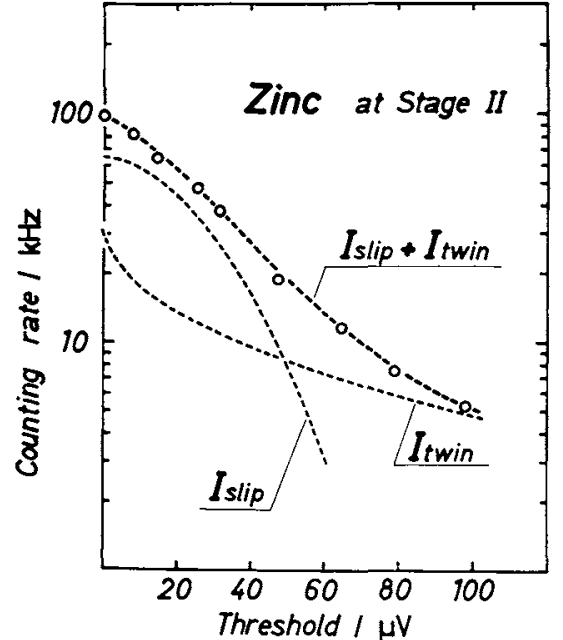

Fig.6 Distribution of $\mathrm{AE}$ amplitudes in the stage II. deformation of zinc single crystal. $I_{\text {stip }}$ and $I_{t w i n}$ correspond to the components of $m=2$ and $m=1 / 2$, respectively. The experimental results are represented as the linear combination of the components of $m=2$ and $m=1 / 2$.

Zn single crystal (70 dB)

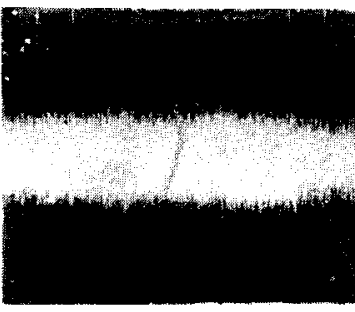

stage I

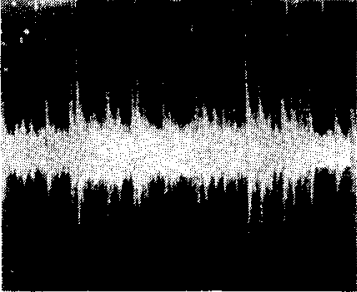

stage II
Noise
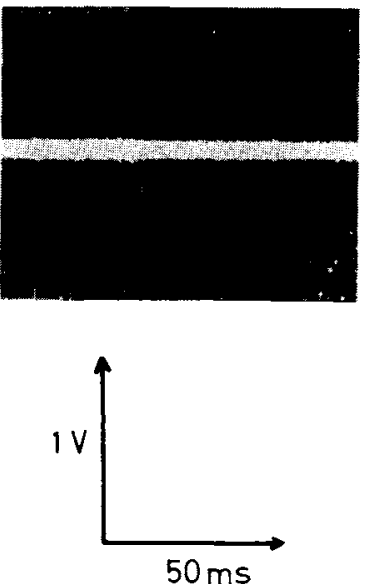

Zn polycrystal $(50 \mathrm{~dB})$

\section{Noise}

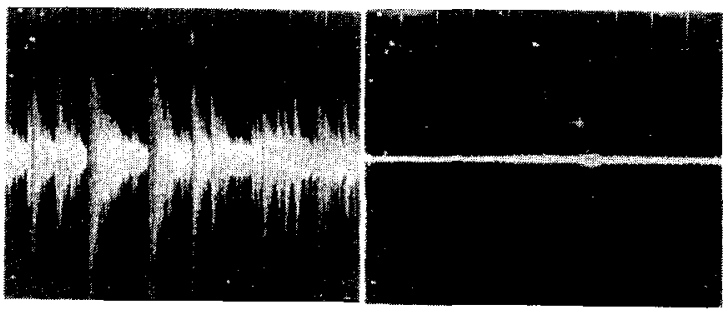

Fig.7 Oscilloscope trace of $\mathrm{AE}$ wave due to the plastic deformation of zinc single and polycrystals. 
Zn 単結晶の变形の stage II に扣いて, 変形双晶の形成 に伴う $\mathrm{AE}$ とすべりによる $\mathrm{AE}$ は，とれぞれ突発型 $\mathrm{AE}$ ， 連続型 $\mathrm{AE}$ であり， $\mathrm{AE}$ 波形そのるの(したがって振幅分 布様式)が異るため，Fig.6 亿示されたような解析を行な うこと汇より，それぞれの成分の全変形に対する奇与を評 洒することができる，一方，多結晶の変形に肪いては，結 晶粒度，ひず反速度，変形温度等により差異が生ずるが， 一般には Fig.7 の波形写真に示されているように，変形双 晶の形成に対応したそれぞれの突発型 $A E$ は，単結晶の stage IIで観察される突発型 $\mathrm{AE}$ よりも枌違いに大きい。

したがって見掛け上はすべりによる連続型 $\mathrm{AE}$ は、それら の突発型 $\mathrm{AE}$ によってすべて遮蔽されて挆り，Fig.8の $\mathrm{AE}$ の振幅分布の戍からあ明らかなよう飞, $\mathrm{Zn}$ 多結晶の 変形飞伴ら $\mathrm{AE}$ は，見掛计上は，すべて突発型成分であ る.

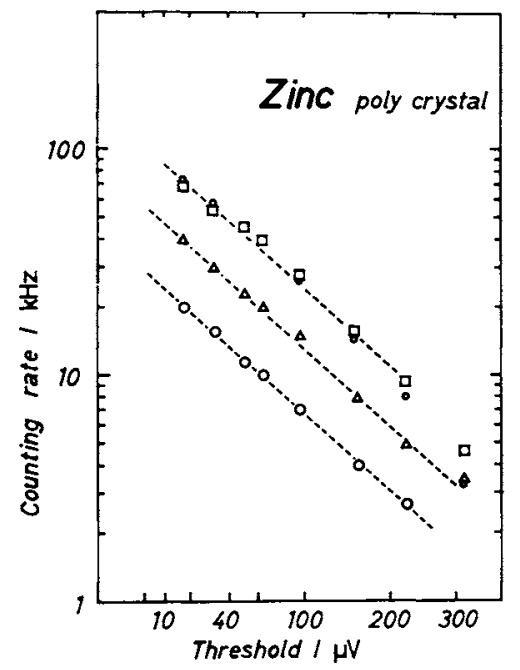

Fig.8 Distribution of AE amplitudes in the plastic deformation of zinc polycrystal. The abscissa indicates the square root of the thre$\operatorname{shold}(m=1 / 2)$.

2. Zn 多結晶の変形に伴う AE の結晶粒度,ひずみ 速度に対する依存性

Fig.9 は種々の結晶粒度を有する $\mathrm{Zn}$ 多結唱の応力・ひ ずみ曲線と $\mathrm{AE}$ 挙動との関係を示している。図上り明らか なように $\mathrm{AE}$ 実效值電厈は結晶粒度に敏感であり，粒度が 大きい汪ど大きな $\mathrm{AE}$ を発生している。これは变形双晶の 形成を伴わない $\mathrm{A} 1$ 多結晶の塑珄変形において観察される $\mathrm{AE}$ の結晶粒度依存性 ${ }^{(22)}$ 之は逆の傾向を示して扬り，しか る $\mathrm{AE}$ の絶対的な大きさむきわめて大きいといら特徵が認 められる.Fig.10は Zn 多結晶に打㚈る AE 実效值電生 のひずみ速度への依存性を示している，AE 実效值電厈は ひずみ速度の平方根に比例するという $\mathrm{Zn}$ 単結晶の stage Iに沶いて観察された結果(Fig.11)とは異り，見掛け上， $\mathrm{AE}$ 実效值電圧はひずみ速度の $1.3 \sim 1.5$ 乗に比例する結 果を与えている．Fig.9および Fig.10 に示された結果は，

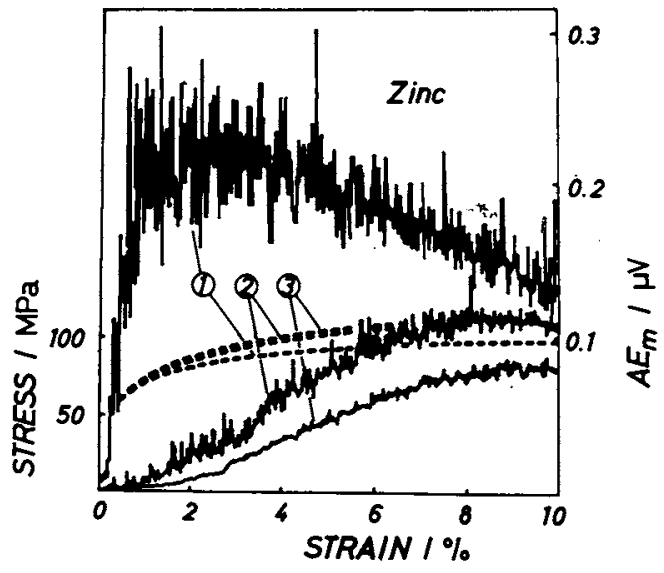

Fig.9 AE behaviors and the related stress-strain curves in zinc polycrystals. (1) $d=350 \mu \mathrm{m}$, (2) $d=95 \mu \mathrm{m}$, (3) $d=40 \mu \mathrm{m}$, where $d$ is the averaged grain diameter.

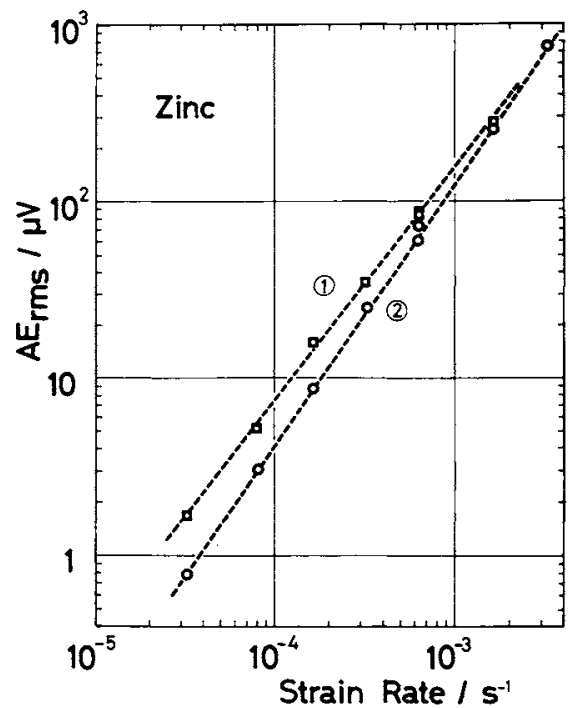

Fig.10 Plastic strain rate dependence of $A E_{r m s}$ in zinc polycrystals. (1) $d=95 \mu \mathrm{m} \quad$ (2) $d=40 \mu \mathrm{m}$

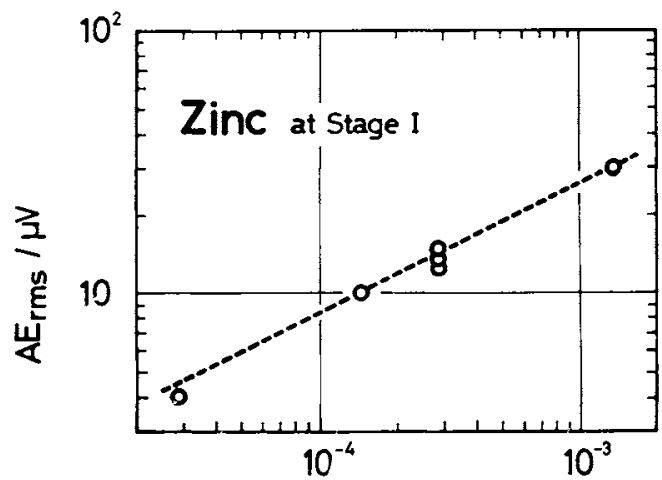

Strain Rate $/ \mathrm{s}^{-3}$

Fig.11 Plastic strain rate dependence of $A E_{r_{m s}}$ in the stage I deformation of zinc single crystal. 
変形双晶の形成頻度が結晶粒度，扣よびひずみ速度の関数 であることを暗示して扣り，結晶粒度，ひずみ速度の変化 に対して敏感に影響をらけることを示唆しているものと若 えられる，特にひずみ速度に対する他の多くの金属の場合 とは異った依存性は，变形双晶の形成頻度が変形速度の関 数であるという点で, 变形双晶の形成頻度が運動学的に取 り扱われらる。あるいは取り报われるべさであるといらこ とを示しているものと理解される。

\section{IV. 考察}

\section{1. $\mathbf{A E}$ の振幅分布より求めた変形双晶の形成頻度}

Zn の変形の stage II Kおける変形双晶の寄与は， $\mathrm{AE}$ の振幅分布を測定することにより，Fig.6に示された方法 から推定されることが理解された。したがって，実際の問 題として, 変形双晶の形成頻度が $\mathrm{AE}$ エネルギーの相対的 強度により評価されると仮定すると, 変形双晶の形成によ る見掛けのひずみ速度は

$$
\dot{\varepsilon}_{t w i n}=\left\{1-\left(A E_{r m s} \mathbb{I}(\text { slip }) / A E_{r m s}{ }^{i(s l i p)}\right)^{2}\right\} \dot{\varepsilon}
$$

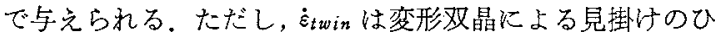

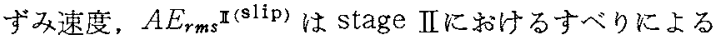
$\mathrm{AE} の$ 実効値電圧, $A E_{r m s}{ }^{i(s 1 i p)}$ は変形双晶の形成を伴わな

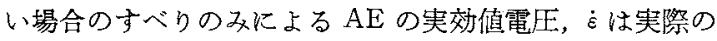
塑性ひずみ速度である.AE の実效值電圧は振幅分布より $m=2$ の場合に対しては $A E_{r m s}=1 / \sqrt{ } \bar{a}$ 与光られる (23)ので, $A E_{r m s}{ }^{i \text { (slip) }}=A E_{r m s}{ }^{\mathrm{I}}$ (ただし $A E_{r m s}{ }^{\mathrm{I}}$ は stage I に扎ける $\mathrm{AE}$ の実效值電压) と仮定し，Fig.5 と Fig.6の 結果から式(3)を計算すると $\dot{\varepsilon}_{t w i n} / \dot{\varepsilon} \approx 0.3$ となる。

変形双晶の形成，伝播の全変形に対する寄与を実験的に 定量するには，変形双晶の体積分率の時間変化を，変形の 進行と対応させながら光学顕微鏡等によって測定するの が，最も基本的であると考党られるが，Znのよらな低融 点金属の室温での変形に打いては，動的な観察以外は，回 復の影響が著しく，さらに観察の不均一性をも考慮に入れ るならば，㵋定結果にはかなりの䛊差が含まれているとい わざるを劣ない，実際問題として，変形双晶の形成，云 播の全変形に対する寄与を定量的に評価した例はすくな く(24), さらに，ひずみ速度等の変形条件の違いによる影 響を問題にした例は，ほとんど報告されていないしたが ってこれらの点を考慮するならば，本節に記された $\mathrm{AE}$ による変形双晶の寄与率の分離定量の手法は，きまぬて有 用なるのであり，今後の多くの発展が期待される。

\section{Zn の变形双晶の形成に関する運動学的取り扱い}

変形双晶の形成，伝播を考えるにあたって，まずはじめ に，変形双晶の発生の条件を与兄る転位の生成，消減の運 動学的方程式を構成する。変形は基本的には転位のすべり 運動だけで記述されるとする。変形双晶は，それによって 緩和されるひずみ，あるいは局所的な応力集中と等価な量 の転位との仮想的な置換によって形成されると考觉る。
すべりに寄与する転位の密度を $n_{s}\left(\mathrm{~m}^{-2}\right), \lambda_{s}$ を転位の消 隇の頻度を表わす係数とし，転位の消減の速度は $-\lambda_{s} n_{s}{ }^{l}$ という反応速度論的な做いによって与えられると仮定す る。ここで，lは転位の消隇の様式に依存した(反応の)次 数である、変形双晶は，結晶内の局所的な応力集中を緩和 するため誘起されると考えられる ${ }^{(25)}$. $h c p$ 金属に䗆いて も特に䚤比の大きな $\mathrm{Zn}, \mathrm{Cd}$ では，㬰効的に活動しうるす ベり系が限定されるため，交差すべりの容易な $b c c$ 金属や 積層欠陷エネルギーの高い $f c c$ 金属に比して，多重すべり を起こすことによって局所的な応力集中を緩和することは 困難である。したがって，多重すべりに代るものとして， 変形双晶の形成が比較的容易に生ずるむのと考古られる. 局所的応力集中の櫭念から理解されるように，結晶粒度や 变形温度等は変形双晶の形成に大きな影響を与え, 特に粒 界による応力緩和が期待できるよらな細かい結晶粒度の場 合，和よび回復の效果の著しい高温においては変形双晶の 形成は当然小さくなることが理解される。これらのことを 念頭に打くならば，变形双晶の形成頻度は，転位密度 $n_{s}$ の みならず転位の増殖頻度 $N$ にも依存することが期待され る、つまり，転位密度がどのよらに大きくとも転位の增殖 がない限りは，転位のパイルアップに起因した局所的応力 集中は起こらず，さらに，転位の增殖速度がどのように大 きくとも，マトリックス中に転位が定常的に有意な量たけ 存在しない限りは，変形双晶は形成されないことになる。 したがって，転位から变形双晶への量的な等価転換の速度 を $f\left(n_{s}, N\right)$ とおくならば， $n_{s}$ の時問変化を与える運動学 的方程式は

$$
d n_{s} / d t=-\lambda_{s} n_{s}{ }^{l}-f\left(n_{s}, N\right)+N
$$

で与兄られることになる。最す簡単な近似として $f\left(n_{\mathrm{s}}, N\right)$ は $n_{s}$ と $N$ の積比例すると仅定すると，式(4)は

$$
d n_{s} / d t=-\lambda_{s} n_{s}^{l}-\mu n_{s} N+N
$$

となる。ただし $\mu\left(\mathrm{m}^{2}\right)$ は，仮想的に転位が変形双晶に等価 転換される時の“転位の捕獲断面積”の概念を表わす量で あり，一つのすべり面上において，变形双晶に等洒転换す る時の臨界転位密度の逆数に比例すると考兄られる。さら に $\mathrm{Zn}$ のよらな純金属の变形は室温で回復律速と考えられ るので

$$
\dot{\varepsilon}=N b x
$$

といらいわゆる free flight motion による条件式(26)(27)を 用いることによって，転位の生成頻度 $N\left(\mathrm{~m}^{-2} \mathrm{~s}^{-1}\right)$ は塑性 ひずみ速度官に関係つけられる。

式(6)の右辺のbはバーガースベクトルであり，xは1本 の転位の生成から消隇要での間の平均移動距離である。式 (4)の右辺に蛙けるlは転位の消減の形態によって決まる 定数であり，通常の実験条件において問題になるのは $l=1$ と $l=2$ の昜合である. $l=1$ は，いわゆる 1 次反応型消減 であり，それぞれの鞋位が热立に上昇運動によってシンク に消隇する過程に対応している， $l=2$ は，いわゆる2次反 応型消隇であり，同一すべり面上での正負の転位の合体消 
減の過程に対応している，通常の実験条件では $l=1$ と $l=2$ の消減過程は共存していると考光られるが, $f c c$ 純金 属に和いて観察されるよらに，転位のすべり速度が上昇速 度よりも十分に大きい時は $l=2$ の過程が支配的になり， 固溶体中の転位の粘性運動 ${ }^{(28)(29)}$ て和いて観察されるよう に，転位の上昇速度に比して，すべり速度が相対的に小さ くなるよらな場合は $l=1$ の過程の寄与が相対的に大さく なると考觉られる。Znに括いては，基本的には交差す心゙ りが存在しないため，Al のよらに積層欠陥エネルギーの 大きな純金属の場合よりも，正負の転位の合体消隇の確率 は小さくなると考えられる，l=1の場合の転位の消隇の係 数である $\lambda_{s}$ は䎐位の平均寿命の屰数に等しく，生成から 消隇までの時間の大小に関係することになる。

式(5)にも゙って，最も簡単な場合として定常的な変形 状態を考える，定常的な変形状態は $d n_{s} / d t=0$ で定義され るので，定常転位密度は，式(5)より

$$
n_{s}= \begin{cases}N /\left(\lambda_{s}+\mu N\right) & \cdots(l=1) \\ -\mu N+\sqrt{\mu^{2} N^{2}+4 \lambda_{s} N} / 2 \lambda_{s} & \cdots(l=2)\end{cases}
$$

と表わされる。 $\mathrm{AE}$ 実效值電圧は変形双晶からの寄与と， すべりからの寄与の両方より決められるとすると

$$
A E_{r m s}=\left(E_{t w i t}+E_{s l i p}\right)^{1 / 2}
$$

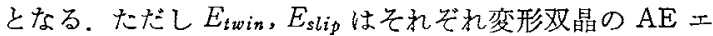

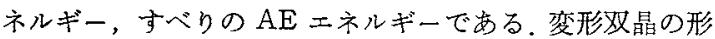
成を伴わないような金属においては AEェネルギーは塑性 ひずみ速度に比例する(3)という事実を，変形双晶の形成之 すべりの共存した状態に拡張することにより，

$$
\begin{aligned}
& E_{t w i n}=A \dot{\varepsilon}_{t w i n} \\
& E_{s l i_{p}}=B \dot{\varepsilon}_{s l i_{p}}
\end{aligned}
$$

と仮定することができる。ただし，A，Bは変形双晶およ びすべりの単位ひずみ速度あたりの $\mathrm{AE}$ エネルギーであ り， $\dot{\varepsilon}_{t w i n}, \dot{\varepsilon}_{s l i p}$ は，それぞれ变形双晶の形成炕よる見掛け のひず速度，すべりによる見掛けのひずみ速度である。 変形は恒等的には式 $(6)$ で記述されるが，定虽的な変形状

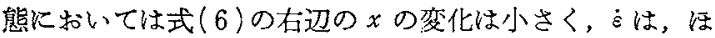
とえどNだけに依存すると考完られる。したがって，式 (5)に打いて, 直接, 変形汇寄与する項は, $N$ の関与する $-\mu n_{s} N+N$ であり，それゆ充 $\mu n_{s}$ は変形双晶の全変形に 対する寄与率を表わしていることになる。したがって

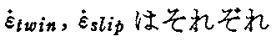

$$
\begin{aligned}
& \dot{\varepsilon}_{t w i n}=\mu n_{s} \dot{\varepsilon} \\
& \dot{\varepsilon}_{s l i p}=\left(1-\mu n_{s}\right) \dot{\varepsilon}
\end{aligned}
$$

で与をられる。式 $(9)$ ，(10)を用いることにより，式 (8) は

$$
A E_{r m s}=\left\{A \dot{\varepsilon} \mu n_{s}+B \dot{\varepsilon}\left(1-\mu n_{s}\right\}^{1 / 2}\right.
$$

となる、Fig.12 は $l=1$ の場合に対して， $\mu=10^{-14}\left(\mathrm{~m}^{2}\right)$ ， $b x=10^{-8}\left(\mathrm{~m}^{-2}\right)$ として，祙をそれぞれ $0.2\left(\mathrm{~s}^{-1}\right), 1.0\left(\mathrm{~s}^{-1}\right)$ ， $5.0\left(\mathrm{~s}^{-1}\right)$ と変化させた時の, 式 $(6),(7)$ より求めた変形 双晶の全变形に対する寄与率 $\mu n_{s}$ を，㐫に対して示したも のである.Fig.13は $l=2$ の場合に対して， $\mu, b x$ は同様

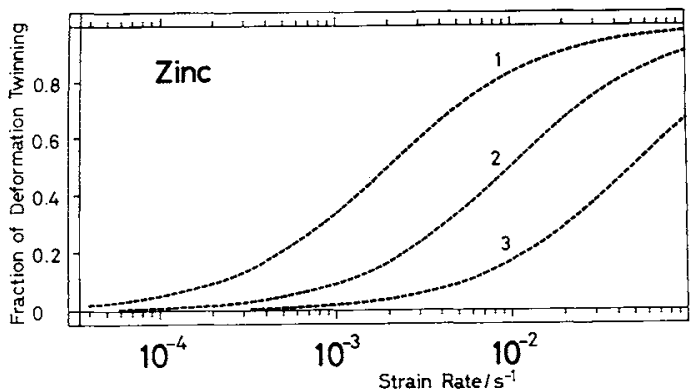

Fig.12 Fraction of deformation twinning $\mu n_{s}$, vs plastic strain rate $(l=1)$.

(1) $\lambda_{s}=0.2 \mathrm{~s}^{-1}$, , (2) $\lambda_{s}=1 \mathrm{~s}^{-1}$ and (3) $\lambda_{s}=5 \mathrm{~s}^{-1}$.

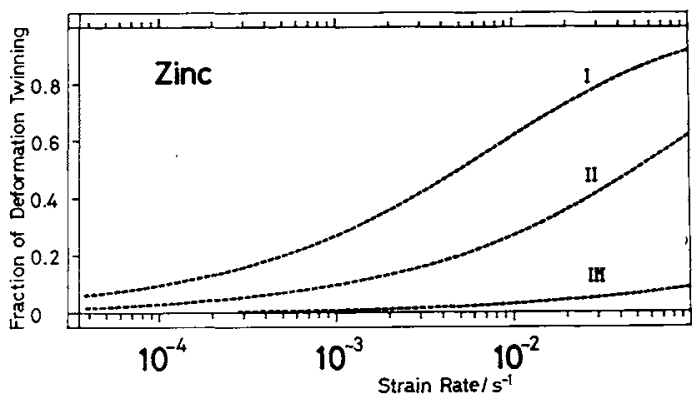

Fig.13 Fraction of deformation twinning, $\mu n_{s}$, vs plastic strain rate $(l=2)$.
(1) $\lambda_{s}=1 \times 10^{-14} \mathrm{~m}^{2} \mathrm{~s}^{-1}$,
(3) $\lambda_{s}=1 \times 10^{-12} \mathrm{~m}^{2} \mathrm{~s}^{-1}$.
(2) $\lambda_{s}=1 \times 10^{-13} \mathrm{~m}^{2} \mathrm{~s}^{-1}$ and

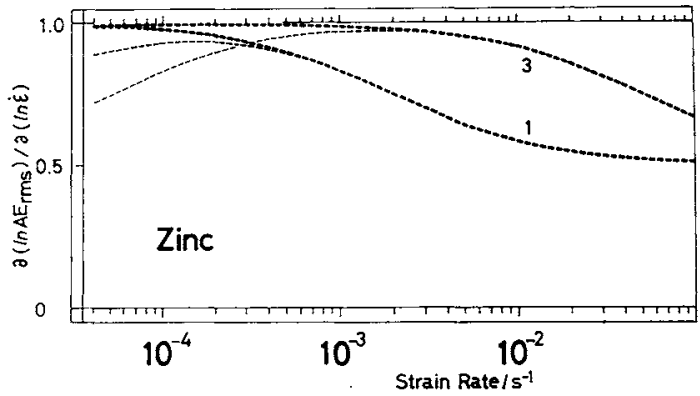

Fig. $14 \partial\left(\ln A E_{r m s}\right) / \partial(\ln \dot{\varepsilon})$ vs plastic strain rate $(l=1)$. (1) $\lambda_{s}=0.2 \mathrm{~s}^{-1}$ and (3) $\lambda_{s}=5 \mathrm{~s}^{-1}$.

The thick and thin dotted lines correspond to the cases that $B / A=5 \times 10^{-5}$ and $B / A=5 \times 10^{-3}$, respectively.

$\partial\left(\ln A E_{r m s}\right) / \partial(\ln \dot{\varepsilon})$ corresponds to the power exponent, $i$, when $A E_{r m s}$ is expressed with the asymptotic form as $A E_{r m s} \propto(\dot{\varepsilon})^{i}$.

として， $\lambda_{s}$ をそれぞれ $1 \times 10^{-14}\left(\mathrm{~m}^{2} \mathrm{~s}^{-1}\right), 1 \times 10^{-13}\left(\mathrm{~m}^{2} \mathrm{~s}^{-1}\right)$ ， $2 \times 10^{-12}\left(\mathrm{~m}^{2} \mathrm{~s}^{-1}\right)$ と変化させた時の $\mu n_{s}$ を它に対して示し たるのである. $l=1 ， l=2$ のいずれの場合にも，ひずみ速 度を増加させると, 変形双晶の全変形に対する寄与率が加 速度的に堌加していく様子が上く示されているが，l=1の 場合の方が增加の程度は著しい. Fig.14は，l=1 の場合 に対してFig.12の結果にもとついて式(11)より計算した $A E_{r m s}$ のひず双速度依存性を示したものである。緃軸は， $A E_{r m s} \propto(\dot{\varepsilon})^{i}$ という幕乗則で表わした場合の見掛忷の指数 
$i\left(=\partial\left(\ln A E_{r m s}\right) / \partial(\ln \dot{\varepsilon})\right)$ を示している. 式(11)の計算には 式(9)で定義された $A, B$ の両者の值が必要であるが， $i$ の計算には $B / A$ の值で十分である。 $B / A$ を啟密に評価す ることは困難であるが，Fig.6 に示されたすべりと変形双 晶の振幅分布の結果から，それぞれの寄与率を考慮に入れ て計算すると $B / A \approx 7 \times 10^{-4}$ と得られる。したがって， iの計算に打いては $B / A$ の影響も検討する意味で $B / A$ を パラメーターとし， $5 \times 10^{-3}$ と $5 \times 10^{-5}$ の二つの場合汇つ いて計算した。因より明らかなよ5に，i性対的に大き なひずみ速度に和いては $B / A$ 飞は依存せず，小さなひ

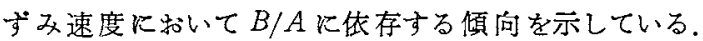
iは，ひずみ速度，扰よび用いたパラメータに依存するか゚ 最大值で 1 ，最小值で将となり， $f c c$ 純金属に打いて通常 観察される $A E_{r m s} \propto(\hat{\varepsilon})^{1 / 2(3)}$ とは異っている. $l=2$ の場合 については， $i$ は最大值で $3 / 4$, 最小值 $1 / 2$ となる。

上述の議論は，すべて定常变形状態に対するすのである が，式（5）火は定常状態だけでなく，非定常状態の解析解 更存在し， $l=1$ に対して

$$
n_{s}(t)=\frac{N}{\lambda_{s}+\mu N}\left\{1-e^{-\left(\lambda_{s}+\mu_{N}\right)_{t}}\right\}
$$

と与えられる。ささらに実際の変形過程では，形成された変 形双晶との境界面は，転位の運動に対して，結晶粒界ある いは亜結晶粒界と同等の役割を果すことを考慮にいれると 変形の進行々とるに事実上の結晶粒度は小さくなると考光 られる。のことは式(5)Kおいて定義された $\lambda_{s}, \mu か ゙ ，$ 実 際の変形の進行とともに変化することを意味して扣り,式 （7）で与えられた定常転位密度 $n_{s}$ は，变形の進行と之む に，ゆっくりと減少することが期待される。 そして，この 效果は，式(12)に示された転位密度の時間变化に比して十 分に小さいと仮定することにより，見掛けの減少保数 $\beta$ $\left(\ll \lambda_{s}+\mu N\right)$ を用いて

$$
n_{s}(t)=\frac{N}{\lambda_{s}+\mu N}\left\{1-e^{-\left(\lambda_{s}+\mu_{N}\right) t}\right\} e^{-\beta t}
$$

と表わされる．Fig.15は，定常転位密度一定のもとに， それぞれのパラメーターを变化させた時の $\mathrm{AE}$ の発生パタ ーンを示している。 ただし $\beta=2 \times 10^{-3}\left(\mathrm{~s}^{-1}\right)$ とした。 それ ぞれのパラメーターは $\beta \ll \lambda_{s}+\mu N$ の関保を満足し，さら に $t=\infty$ で等しいで等しい枟位密度を与えるように決めら れた。図より容易に理解されるように，AEの発生パター ンは，定常転立密度が一定であっても，特に变形の初期似 煔いて大きく異なり， $\lambda_{s}$ の值に敏感であることが理解でき 万.

以上の結果に上り，変形双晶の形成とすべりが共存する 場合の変形と $\mathrm{AE}$ の挙動は式(5)で記述されることが理解 されたが，本解析用いられたパラメーター $\lambda_{s} ， \mu$ は，種々 の金属学的因子や実験条件，例总ば，結晶粒度，变形温度， ひず文速度に依存すると考元られる。その他，変形双晶の 形成条件に影響を与学る因子として考慮され朴ばならない のは結晶学的な異方性であり，Zn亿战いては压延方向と

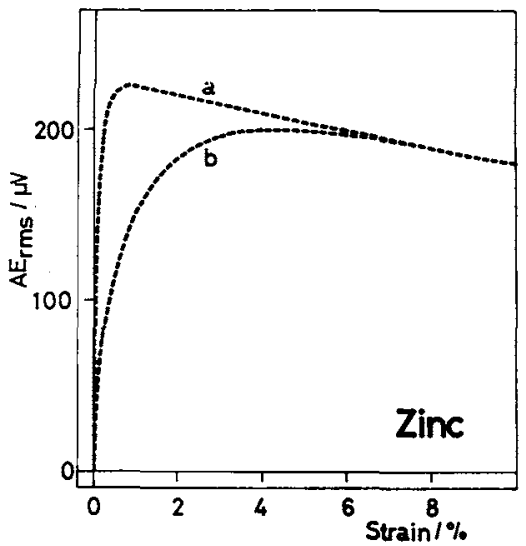

Fig.15 AE profiles as a function of plastic strain, which is based upon eq. (13).

(a) $\lambda_{s}=0.2 \mathrm{~s}^{-1}, \mu=1 \times 10^{-14} \mathrm{~m}^{2}, N / \dot{\varepsilon}=1 \times 10^{16} \mathrm{~m}^{-2}$ and $\dot{\varepsilon}=4 \times 10^{-4} \mathrm{~s}^{-1}$

(b) $\lambda_{s}=0.02 \mathrm{~s}^{-1}, \mu=1 \times 10^{-14} \mathrm{~m}^{2}, N / \dot{\varepsilon}=1 \times 10^{15} \mathrm{~m}^{-2}$ and $\dot{\varepsilon}=4 \times 10^{-4} \mathrm{~s}^{-1}$.

直角份鿓荷した場合に変形双晶の形成頻度が大きく，した がって大きな $\mathrm{AE}$ を発生させる。この結晶学的な異方性と

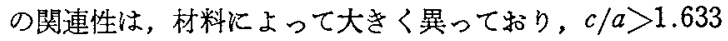
といら条件を満足する $\mathrm{Zn}$ ，Cd 抹いては上述の上らであ り，Ti のように $c / a<1.633$ の材料では，Zn の場合と逝 の傾向を示すことが知られている ${ }^{(30)}$.

\section{V. 結 論}

Zn において变形双晶の形成, 伝播に伴う $\mathrm{AE}$ の挙動に 関して，種々の考察を加えることにより以下に述べるょう な結論を得た。

(1) Zn の変形恃(底面)すべりと変形双晶の形成, 伝播 といら二つの異った変形様式から構成されて蛙り，AEの 発生パターン，および波形の観察を行ならことにより，Zn 単結晶の変形の初期(stage I)では，主としてすべりによ る連続型 $\mathrm{AE}$ 波の成分が多く, 变形の進行とともに变形双 晶の形成，伝播に対応した鋭い突発型の $\mathrm{AE}$ 波が放出され ていることが理解された。そして，それぞれの成分連 綕型, 突発型) の振幅分布形態の違いから, 全变形に対す る変形双晶の形成，伝播の寄与率を算出することが可能で あり，Zn 単結晶の変形の stage IIに対して適用すると， 恋形双晶の寄与率は約 0.3 と得られた。

(2) $\mathrm{Zn}$ 多結晶の变形に伴う AE 飞関しては，結晶粓度， ひずみ速度等によって異るが，一般的には，単結晶の場合 に比して，変形双晶の形成，伝播に伴ら $\mathrm{AE}$ のエネルギ 一はすべりに伴う $\mathrm{AE}$ のエネルギーよりる妳違いに大き く、現象論的には測定された $\mathrm{AE}$ は㱠ど变形双晶の形成，公 播によるあのと考えることができる、したがって，AE 活動 度の変形条件による違い变形双晶の形成頻度の違いを意 味して扣り，逆に $\mathrm{AE}$ の測定結果から变形双晶の形成頻度 を評価することが可能になる。本論文においては，以上の 
点を考慮して, 転位の生成, 消隇之変形双晶の形成に関し て運動学的取り扱いを構成することにより，AE 活動度を 半理論的に説明し，例宎ば $\mathrm{AE}$ 活動度の昰速度依存性，抹 よび変形に伴う $\mathrm{AE}$ 活動度の変化について半定量的に評価 することに成场した。

\section{文献}

(1) K.Ono : FUNDAMENTALS OF ACOUSTIC EMISSION, UCLA, (1979), 167.

(2) J.Kaiser : Arch. Eisenhütt., 24(1953) , 43.

(3) T.Kishi and K.Kuribayashi : FUNDAMENTALS OF ACOUSTIC EMISSION, UCLA, (1979), 105.

(4) R.M.Fisher and J.S.Lally : Canadian Journal of Physics, 45(1967), 1147.

(5) P.P.Gillis and M.A.Hamstad : Mat. Sci. Eng., 14(1974), 103.

(6) R.Pascual : Scripta Met., 8(1974), 1461.

(7) H.L.Dunegan and D.O.Harris: U1trasonics, 7 (1969), 160 .

(8) D.R.James and S.H.Carpenter : J.Appl.Phys., $42(1971), 4685$.

(9) T.Imanaka, K.Sano and M.Shimizu : Crystal Lattice Defects, 4(1973), 57.

(10) E.Siege1 : Acta Met., 25(1977), 383.

(11) R.W.B.Stephens and A.A.Pollock : J.Acoust. Soc.Am., 50 (1961), 904 .

(12) K. Malen and L.Bolin : Phys. Status Solidi, (b) $61(1974), 637$.

(13) K.Kuribayashi, T.Kishi, K.Ohno and R. Horiuchi: Proceedings, Int. Conf. AE, Anaheim, 1979, (in press).
(14) M.Kleintges, R.Labusch, H.G.Broin and P. Haasen : Acta Met., 25(1977), 1247.

(15) H.C.van Elst : Trans. Met. Soc. AIME, 230 (1964), 460.

(16) 西山善次：マルテンサイト変態, 基本編, 丸善, (1971), p.169.

(17) R.F.Bunshah : DEFORMATION TWINNING, R.E.Reed-Hill, J.P.Hirth and H.C.Rogers, Eds., Gordon and Breach, New York, (1964), p. 390 .

(18) J.P.Toronchuk: Materials Evaluation/Octobar, $37(1977), 51$.

(19) 日本溶接協会原子力研究委員会 FAE小委員会, 昭 和 53 年度動然委託研究成果報告書 J225 79-02, JWES-AE-7903(1979), July pp.3-11.

(20) E.Schmid and W.Boas : PLASTICITY OF CRYST ALS, F.A.Hughes \& Co.Ltd., London, (1950), p.77.

(21) 岸 辉雄, 加藤 明, 栗林一彦, 堀内 良：日本金 属学会誌，41(1977)，897.

(22) 田中 博, 岸 胱雄, 堀内 良: 第 1 回 $\mathrm{AE}$ 総合 ンファレンス論文集, 東京, (1977)，pp.149-155.

(23) J.Eisenblatter, P.Jax and H.J. Schwalbe: Proceedings, 2nd AE Symp., Tokyo, Japan, (1974), session 7,p.1.

(24) R.E.Reed-Hill : Ref.17, p.295.

(25) R.W.Cahn : Ref.17, p.1.

（26）吉永日出男, 当摩 建, 諸住证太郎：日本金属学会 誌, 39(1975), 626 .

(27) 竹内 伸：金属物理セミナー，2(1977)，89.

(28) 堀内 良, 大塚正久: 日本金属学会誌, 35(1971), 406.

(29) 吉永日出男：日本金属学会会報，17(1978)，414，

(30) H.Tanaka and R.Horiuchi: Scripta Met., 9 (1975), 777 . 